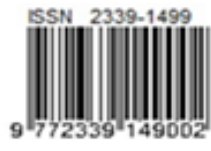

\title{
ANALISIS PRODUKTIVITAS MENGGUNAKAN METODE POSPAC DAN PERFORMANCE PRISM SEBAGAI UPAYA PENINGKATAN KINERJA (Studi Kasus: Industri Baja Tulangan di PT. X Surabaya)
}

\author{
Rony Prabowo ${ }^{1}$, Rizal Aditia ${ }^{2}$ \\ ${ }^{1,2)}$ Fakultas Teknologi Industri, Jurusan Teknik Industri, Institut Teknologi Adhi Tama Surabaya \\ Jl. Arief Rahman Hakim 100, Surabaya 60117 \\ Email: rony.prabowo@itats.ac.id dan Rizaladitia25@gmail.com,
}

\begin{abstract}
This study aims to identify the partial productivity index and performance measurement in order to make efforts to increase the productivity of the production section at PT. $X$ Surayaba which produces reinforcing steel using a rolling mill with POSPAC method and Performance Prism. Through productivity measurement POSPAC method obtained fluctuating results every month in each indicator the highest productivity ratio in the labor indicator in the July period with a productivity ratio of 76.96 and a productivity index of $123 \%$, for the measurement of the lowest productivity in the product indicator the value of the productivity ratio of 0.61 and the productivity index of $87 \%$. Through the Performance Prism method it is known that labor indicators need to be improved because based on $\mathrm{KPI}$ values only get a value of $29 \%$ due to low disciplinary factors and less effective at work.
\end{abstract}

Keywords : productivity; production; performance; prism; effective

\begin{abstract}
Abstrak
Penelitian ini bertujuan untuk mengidentifikasi indeks produktivitas parsial dan pengukuran kinerja agar dapat melakukan upaya peningkatan produktivitas bagian produksi di PT. X Surayaba yang memproduksi baja tulangan menggunakan rolling mill dengan metode POSPAC dan Performance Prism. Melalui pengukuran produktivitas metode POSPAC diperoleh hasil yang fluktuatif pada setiap bulan di setiap indikatornya rasio produktivitas tertinggi pada indikator tenaga kerja pada periode Juli dengan rasio produktivitas sebesar 76,96 dan indeks produktivitas sebesar $123 \%$, untuk pengukuran produktivitas terendah pada indikator produk nilai rasio produktivitas sebesar 0,61 dan indeks produktivitas sebesar $87 \%$. Melalui metode Performance Prism diketahui indikator tenaga kerja yang perlu untuk diperbaiki karena berdasarkan nilai KPI hanya memperoleh nilai $29 \%$ karena rendahnya faktor kedisiplinan dan kurang efektif dalam bekerja.
\end{abstract}

Kata kunci : produktivitas; produksi; performance; prism; efektif

\section{Pendahuluan}

Perusahaan harus mampu melakukan fungsi koordinasi di seluruh deprtemen atau divisinya terutama terkait dengan penggunaan sumber daya. Secara cepat perusahaan harus dilengkapi dengan sistem manajemen dan pengendalian sumber daya manusia yang menjadi motor serta faktor produksi dalam peranan perusahaan. Misalnya pada industri manufaktur yang mampu menyerap tenaga kerja dan kemampuan dalam menciptakan nilai tambah (value added creation) dari setiap bahan yang diolah beserta inputnya, hal itu membuat untuk mendapatkan peranan penting dalam pembangunan nasional karena nilai kapitalisasi modal yang tertanam sangat besar pada industri manufaktur (Nelly and Kennerley, 2012; Prabowo, 2016, Wibowo, 2018). Oleh sebab itu perusahaan perlu melakukan pengukuran produktivitas. Produktivitas harus bisa dipertahankan bagi perusahaan agar dapat menjaga kestabilan perusahaan untuk menjadi efektif dan efisien dalam menjalankan aktivitas produksi misalnya pada tenaga kerja, bahan baku, penjualan, dan organisasi, serta hal finansial atau modal (Prabowo, 2017, Suryanto, 2014). Penelitian ini bertujuan untuk: (1) mengidentifikasi indeks produktivitas dengan pengukuran produktivitas dengan metode pengukuran produktivitas parsial POSPAC dan perfrormance Prism; dan (2) Mengetahui upaya peningkatan produktivitas 
perusahaan melalui integrasi metode POSPAC dan Performance Prism.

Metode yang digunakan untuk pengukuran produktivitas pada penelitian ini yaitu metode produktivitas parsial POSPAC, keuntungan model tersebut menyajikan secara lengkap elemen-elemen parsial perusahaan yang dipakai untuk mengukur produktivitas parsial perusahaan (produksi, organisasi, penjualan, produk, tenaga kerja dan modal), serta bila ada penurunan produktivitas dari salah satu unit, tindakan perbaikan dapat segera dilakukan untuk meningkatkan produktivitas pada masing-masing unit tersebut (Syarifuddin \& Yani, 2014; Widodo, 2009). Pengukuran kinerja yang digunakan berasal dari visi dan strategi badan usaha yang dijabarkan dalam lima perspektif Performance Prism sehingga membentuk sebuah framework (kerangka) Performance Prism. Selanjutnya akan diidentifikasikan siapa saja stakeholder dalam perusahaan untuk dicari keinginan maupun kebutuhannya dan dilakukan pengukuran kinerja pada setiap stakeholder perusahaan. Kelebihan menggunakan metode ini adalah susunan yang berkontribusi pada organisasi. Secara jelasnya meliputi investor, pelanggan, karyawan, supplier, dan masyarakat (Agustina, 2011; Supriyanto, et.al, 2014; Syarifuddin, et.al, 2017). Dengan melakukan pengukuran produktivitas merupakan suatu tindakan atau bisa dibilang indikator utama dalam memberikan penilaian bersaing pada suatu perusahaan (Purnomo \& Hadi, 2017; Ramadhani, 2011). Produktivitas merupakan suatu istilah yang sering digunakan dalam perencanaan pengembangan industri pada khususnya dan perencanaan pengembangan ekonomi nasional pada umumnya. Tingkat produktivitas tidak hanya dilihat dari aspek kuantitas tetapi juga aspek kualitas baik dari produknya maupun dari tenaga kerja yang memproduksi (Prabowo, 2017; Wibowo, 2018).

Metode POSPAC (Production, Organization, Sales, Product, Arbeteiter dan Capital) merupakan alat ukur yang digunakan sebagai pengukuran produktivitas parsial. Model POSPAC juga dikenal dengan roda produktivitas Habberstad, yang biasanya dijadikan sebagai referensi acuan atau tolak ukur bagi para industriawan dalam usaha mengukur dan meningkatkan produktivitas dibidang industri (Prabowo, 2016; Syarifuddin dan Yani, 2014; Supriyanto, et al, 2017). Model POSPAC mengevaluasi beberapa faktor, antara lain mengevaluasi sumber daya berdasarkan alokasi dana produktivitas, dengan elemen-elemen yang diukur yaitu produksi, penjualan, organisasi, tenaga kerja, produk, dan modal (Agustina, 2011; Suryanto, 2014). Dimana terdapat rasio yang saling mempengaruhi setiap inputnya. Model Habberstad ini terdiri atas enam ukuran produktivitas parsial yaitu Production, Organization, Sales, Product, Arbeiter, dan Capital (atau dikenal juga dengan POSPAC) (Prabowo, 2017; Syarifuddin dan Yani, 2014). Sedangkan metode performance prism merupakan pendekatan oleh manajemen kinerja yang bertujuan untuk memenuhi semua dari setiap aspek yang terlibat didalamnya. Dengan model ini dilakukan sebuah pendekatan dari aspek kepuasan (satisfaction) dan aspek kontribusi (contribution), sehingga pengambilan keputusan tidak berdasarkan pada keberhasilan strategi perusahaan. Dari penjelasan tersebut maka dapat dijelaskan dasar pengukuran Performance Prism antara lain (Neely, et. al, 2012) stakeholder satisfaction, stakeholder contribution, strategies, process dan capability.

\section{Metodologi Penelitian}

Metode penelitian merupakan sebuah tahapan-tahapan penelitian sebagai kerangka pemikiran dalam memecahkan masalah agar penelitian yang dilakukan berjalan secara sistematis dan terstruktur yang dapat dilihat pada Gambar 1. Identifikasi dan perumusan masalah merupakan penggalian masalah yang terjadi di perusahaan dimaan selanjutnya dilakukan studi pustaka terkait dengan konsep POSPAC dan Performance Prism. Data penelitian diperoleh dari wawancara dan observasi sehingga menghasilkan data primer dan data sekunder. 

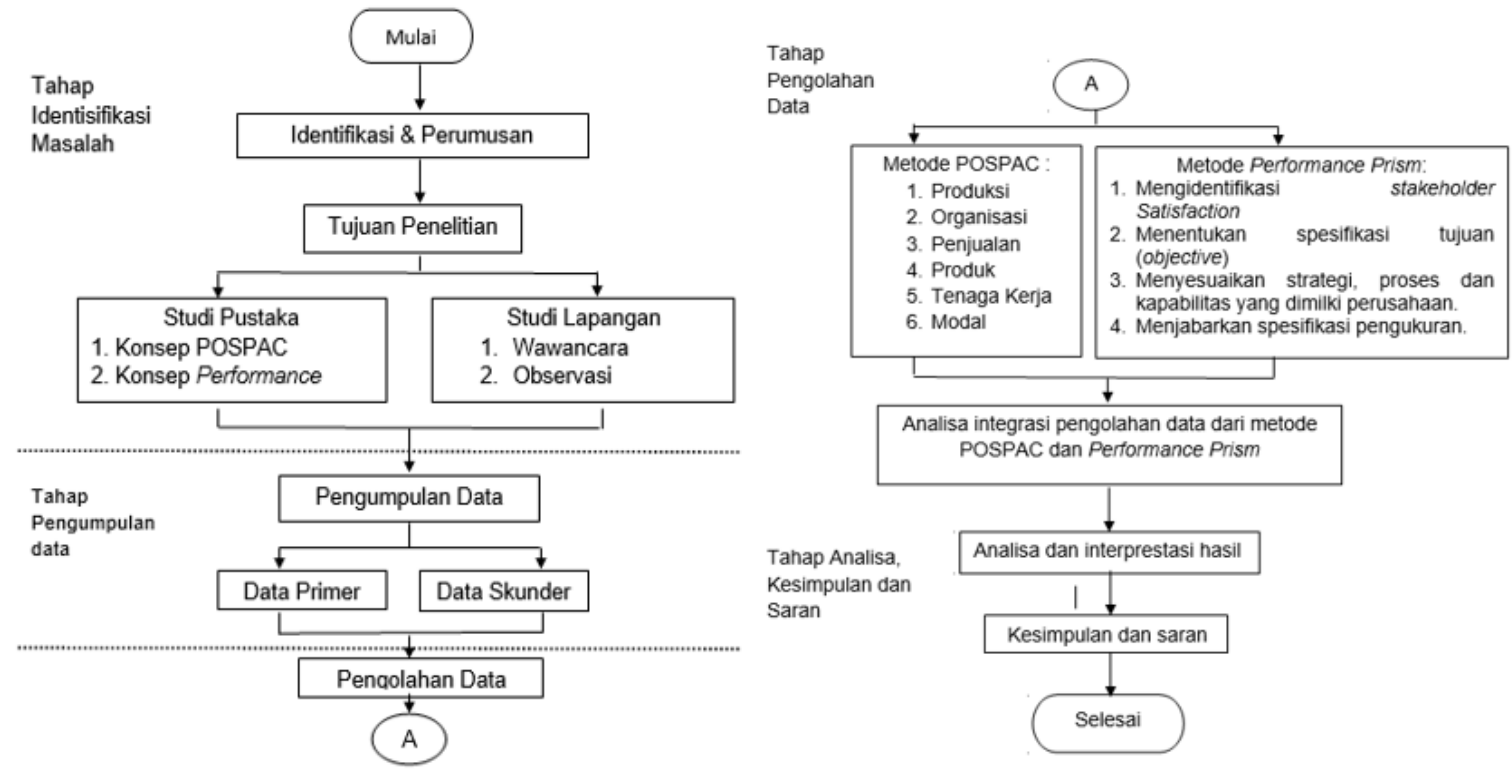

Gambar 1. Diagram Alir Metode Penelitian

Selanjutnya setelah data diperoleh dilakukan pengolahan data melalui metode POSPAC dengan mempertimbangkan aspek produksi, organisasi, penjualan, produk, tenaga kerja, dan modal. Sedangkan metode Performance Prism dengan langkah-langkah mengidentifikasi stakeholder satisfaction, menentukan spesifikasi tujuan (objective), menyesuaikan strategi proses dan kapabilitas yang dimiliki perusahaan serta menjabarkan spesifikasi pengukuran.

Tahapan berikutnya adalah melakukan analisa hasil dari integrase POSPAC dan Performance Prism dimana akan dilanjutkan dengan memberikan kesimpulan dan saran.

\section{Analisa dan Pembahasan}

\section{Produktivitas Produksi}

Dalam perhitungan pengukuran produktivitas produksi telah diperoleh hasil pada Tabel 1, Gambar 2 dan 3.

Rasio produktivitas

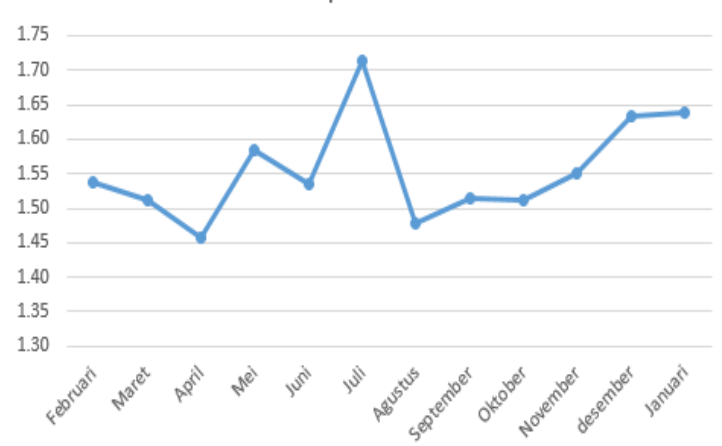

Gambar 2. Grafik Rasio Produktivitas

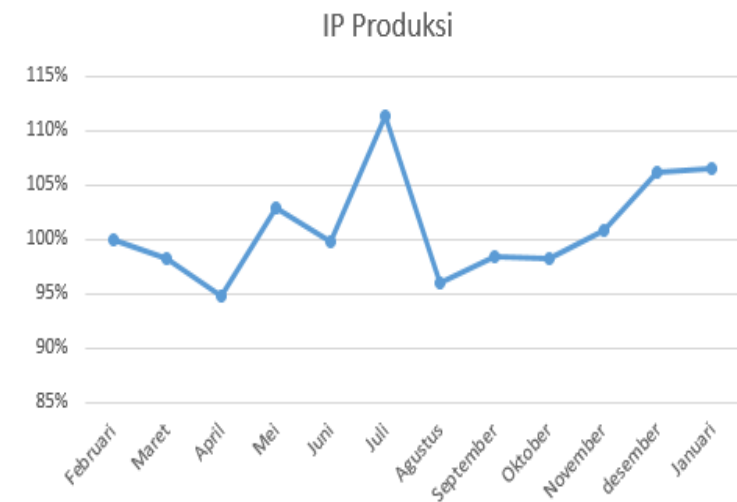

Gambar 3. Grafik Perhitung Indeks Produktivitas Produksi

\section{Produktivitas Organisasi}

Dalam perhitungan pengukuran produktivitas organisasi telah diperoleh hasil pada Tabel 2, Gambar 4, dan Gambar 5.

Rasio produktivitas Organisasi

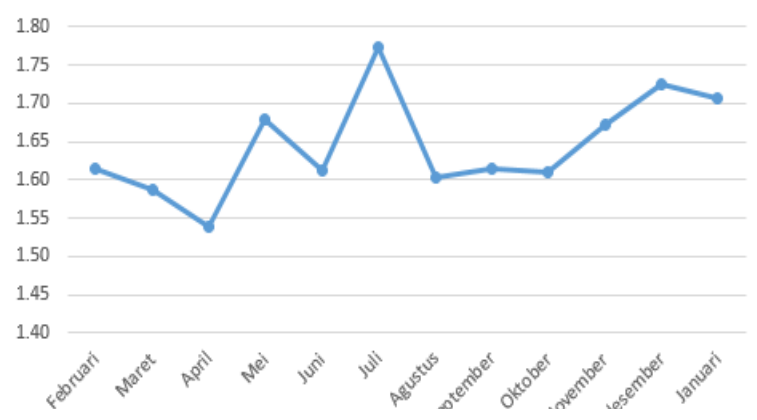

Gambar 4. Grafik Perhitungan Rasio Produktivitas Organisasi 
IP Organisasi

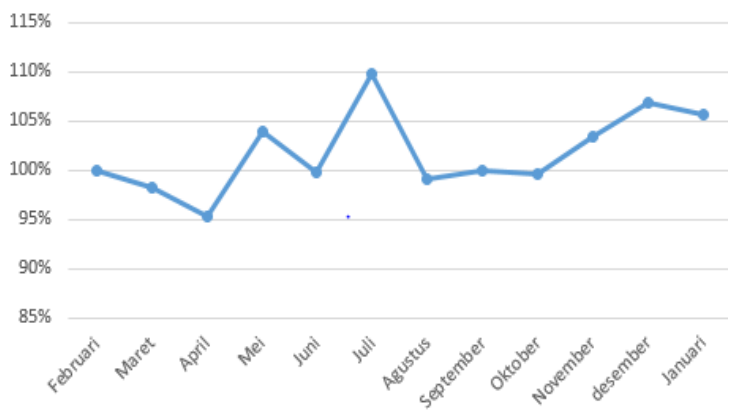

Gambar 5. Grafik Perhitungan Indeks Produktivitas Organisasi

\section{Produktivitas Penjualan}

Dalam perhitungan pengukuran produktivitas penjualan telah diperoleh hasil pada Tabel 3, Gambar 6, dan Gambar 7.

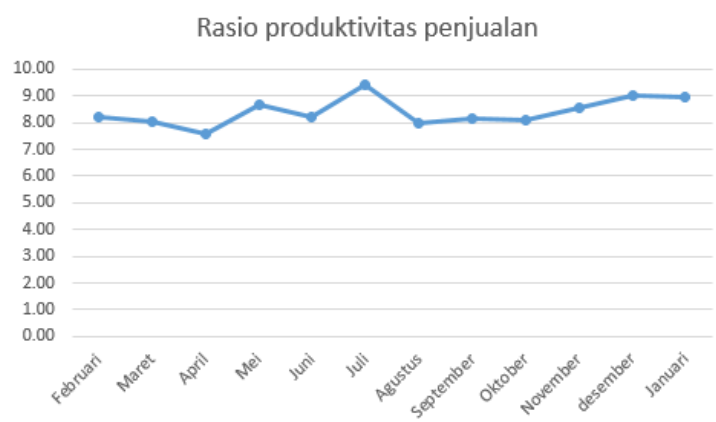

Gambar 6. Grafik Perhitungan Rasio Produktivitas Peniualan

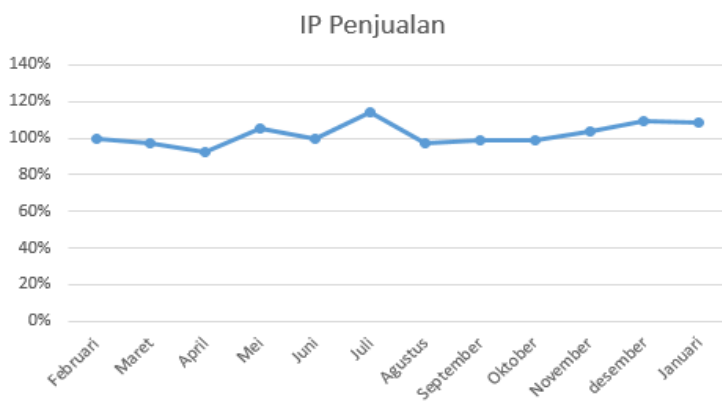

Gambar 7. Grafik Perhitungan Indeks Produktivitas Peniualan

\section{Produktivitas Produk}

Dalam perhitungan pengukuran produktivitas produk telah diperoleh hasil pada Tabel 4, Gambar 8, dan 9.

\section{Produktivitas Tenaga Kerja}

Dalam perhitungan pengukuran produktivitas tenaga kerja telah diperoleh hasil pada Tabel 5, Gambar 10, dan 11.

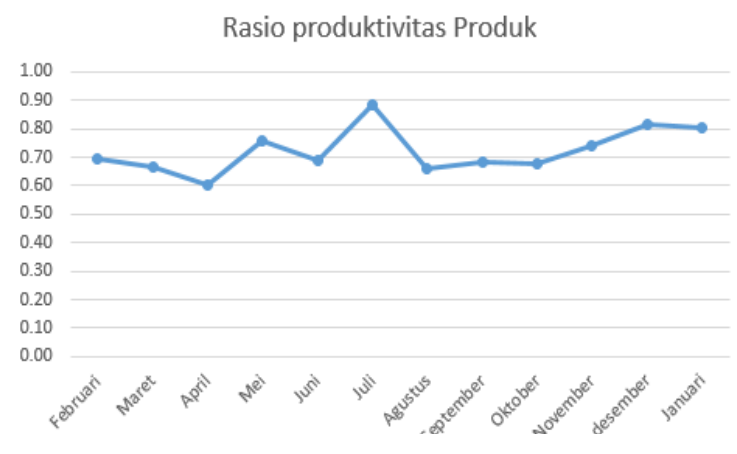

Gambar 8. Grafik Perhitungan Produktivitas Produk

IP produk

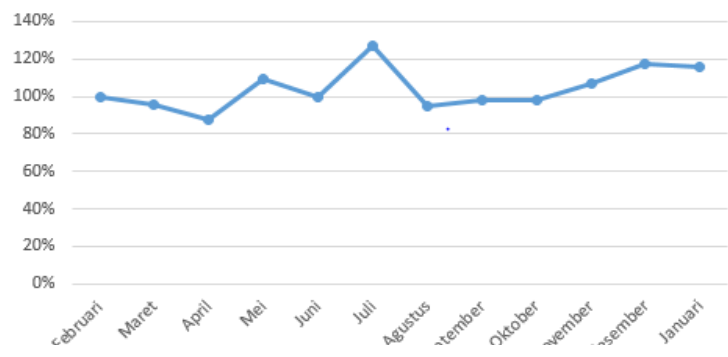

Gambar 9. Grafik perhitungan Indeks Produktivitas Produk

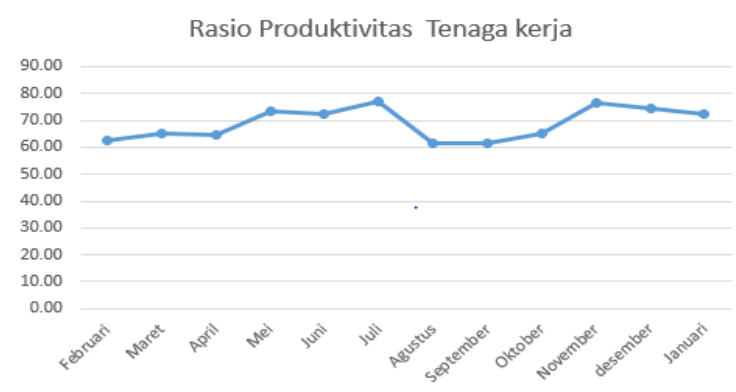

Gambar 10. Grafik Perhitungan Rasio Produktivitas Tenaqa Keria

IP Tenaga Kerja

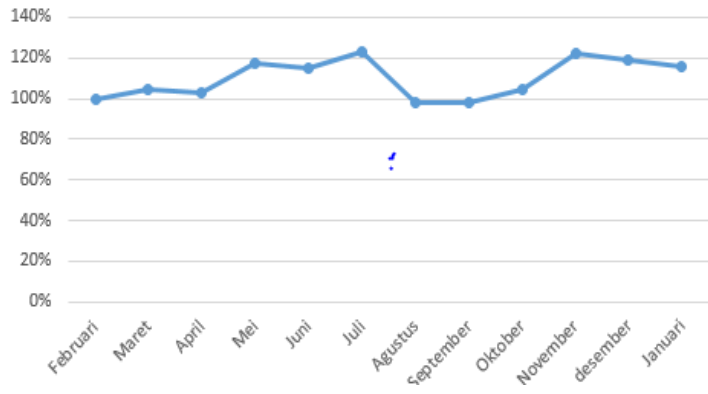

Gambar 11. Grafik Indeks Produktivitas Tenaga Kerja

\section{Produktivitas Modal}

Dalam perhitungan pengukuran produktivitas tenaga kerja telah diperoleh hasil pada Tabel 6 , Gambar 12 dan 13. 
Rasio produktivitas Modal

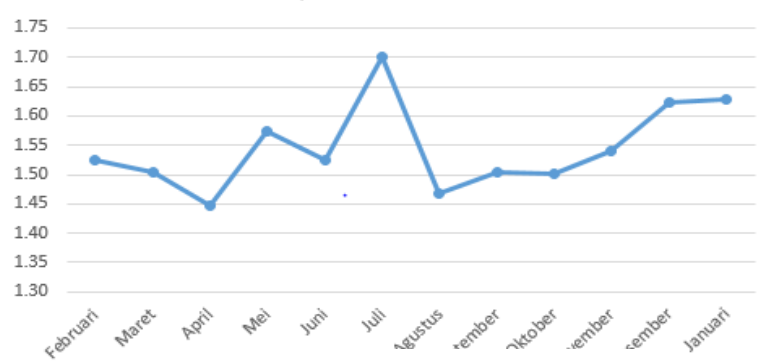

Gambar 12. Grafik Perhitungan Rasio Produktivitas Modal

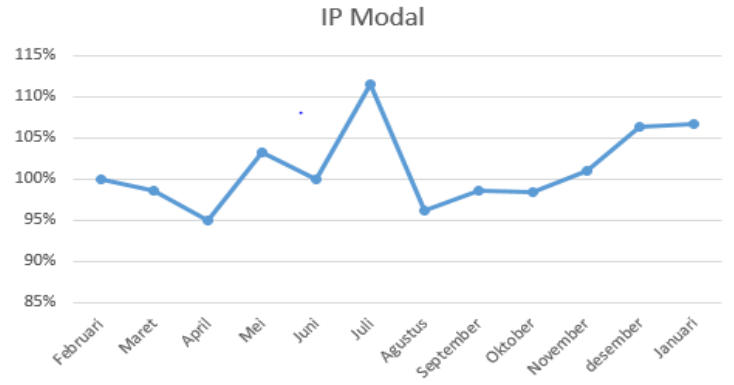

Gambar 13. Grafik Perhitungan Indeks Produktivitas Modal

Tabel 1. Hasil Perhitungan Produktivitas Produksi

\begin{tabular}{|l|c|c|c|c|}
\hline Bulan & $\begin{array}{c}\text { Pendapatan } \\
\text { Bersih (Rp) }\end{array}$ & $\begin{array}{c}\text { HPP } \\
(\mathbf{R p})\end{array}$ & $\begin{array}{c}\text { Rasio } \\
\text { Produktivitas }\end{array}$ & $\begin{array}{c}\text { IP } \\
\text { Produksi }\end{array}$ \\
\hline FEB. & $210.459 .456 .536,-$ & $136.785 .076 .468,-$ & 1,54 & $100 \%$ \\
\hline MAR. & $224.911 .964 .543,-$ & $148.721 .352 .395,-$ & 1,51 & $98 \%$ \\
\hline APR. & $236.179 .593 .777,-$ & $162.057 .948 .346,-$ & 1,46 & $95 \%$ \\
\hline MEI & $233.728 .272 .466,-$ & $147.494 .550 .170,-$ & 1,58 & $103 \%$ \\
\hline JUN & $243.287 .655 .571,-$ & $158.413 .533 .418,-$ & 1,54 & $100 \%$ \\
\hline JUL & $225.989 .305 .190,-$ & $131.955 .553 .808,-$ & 1,71 & $111 \%$ \\
\hline AGU. & $212.519 .756 .626,-$ & $143.783 .388 .077,-$ & 1,48 & $96 \%$ \\
\hline SEP. & $208.288 .391 .504,-$ & $137.561 .480 .105,-$ & 1,51 & $98 \%$ \\
\hline OKT. & $222.491 .858 .319,-$ & $147.236 .907 .980,-$ & 1,51 & $98 \%$ \\
\hline NOP. & $247.949 .706 .593,-$ & $159.799 .813 .075,-$ & 1,55 & $101 \%$ \\
\hline DES. & $229.103 .915 .295,-$ & $140.190 .500 .341,-$ & 1,63 & $106 \%$ \\
\hline JAN. & $242.481 .958 .033,-$ & $147.985 .853 .718,-$ & 1,64 & $106 \%$ \\
\hline SUmber : & 2ata & & \\
\hline
\end{tabular}

Sumber : Data Internal Perusahaan (2018 - 2019)

Tabel 2. Hasil Perhitungan Produktivitas Organisasi

\begin{tabular}{|c|c|c|c|c|}
\hline Bulan & $\begin{array}{c}\text { Nilai Tambah } \\
(\mathbf{R p})\end{array}$ & $\begin{array}{c}\text { Biaya Umum } \\
(\mathbf{R p})\end{array}$ & $\begin{array}{c}\text { Rasio } \\
\text { Produktivitas }\end{array}$ & $\begin{array}{c}\text { IP } \\
\text { Organisasi }\end{array}$ \\
\hline FEB. & $230.760 .231 .559,-$ & $142.828 .297 .478,-$ & 1,62 & $100 \%$ \\
\hline MAR. & $246.054 .415 .993,-$ & $154.956 .254 .683,-$ & 1,59 & $98 \%$ \\
\hline APR. & $258.940 .885 .835,-$ & $168.250 .550 .137,-$ & 1,54 & $95 \%$ \\
\hline MEI & $256.890 .132 .136,-$ & $152.929 .964 .240,-$ & 1,68 & $104 \%$ \\
\hline JUN & $266.223 .999 .253,-$ & $165.156 .902 .212,-$ & 1,61 & $100 \%$ \\
\hline JUL & $246.570 .219 .391,-$ & $139.044 .337 .238,-$ & 1,77 & $110 \%$ \\
\hline AGU. & $235.589 .778 .525,-$ & $147.037 .776 .599,-$ & 1,60 & $99 \%$ \\
\hline SEP. & $229.521 .783 .491,--$ & $142.216 .083 .346,-$ & 1,61 & $100 \%$ \\
\hline OKT. & $245.030 .841 .491,--$ & $152.091 .697 .425,-$ & 1,61 & $100 \%$ \\
\hline NOP. & $274.049 .929 .598,-$ & $163.873 .995 .314,-$ & 1,67 & $104 \%$ \\
\hline DES. & $251.624 .002 .659,-$ & $145.797 .614 .061,-$ & 1,73 & $107 \%$ \\
\hline JAN. & $264.937 .486 .611,--$ & $155.299 .070 .154,-$ & 1,71 & $106 \%$ \\
\hline
\end{tabular}

Sumber : Data Internal Perusahaan (2018 - 2019) 
Tabel 3. Hasil Perhitungan Produktivitas Penjualan

\begin{tabular}{|c|c|c|c|c|}
\hline Bulan & $\begin{array}{c}\text { Laba Kotor } \\
\text { (Rp.) }\end{array}$ & $\begin{array}{c}\text { Biaya } \\
\text { Penjualan (Rp) }\end{array}$ & $\begin{array}{c}\text { Rasio } \\
\text { Produktivitas }\end{array}$ & $\begin{array}{c}\text { IP } \\
\text { Penjualan }\end{array}$ \\
\hline FEB. & $91.285 .681 .418,-$ & $11.106 .750 .874,-$ & 8,22 & $100 \%$ \\
\hline MAR. & $95.131 .048 .852,-$ & $11.866 .059 .190,-$ & 8,02 & $98 \%$ \\
\hline APR. & $94.290 .123 .867,-$ & $12.460 .817 .308,-$ & 7,57 & $92 \%$ \\
\hline MEI & $106.904 .712 .131,-$ & $12.331 .987 .897,-$ & 8,67 & $105 \%$ \\
\hline JUN & $105.243 .163 .117,-$ & $12.835 .263 .323,-$ & 8,20 & $100 \%$ \\
\hline JUL & $112.232 .568 .722,-$ & $11.920 .698 .829,-$ & 9,41 & $115 \%$ \\
\hline AGU. & $89.348 .974 .581,-$ & $11.210 .125 .221,-$ & 7,97 & $97 \%$ \\
\hline SEP. & $89.496 .693 .356,-$ & $10.989 .109 .293,-$ & 8,14 & $99 \%$ \\
\hline OKT. & $95.319 .789 .363,-$ & $11.736 .622 .678,-$ & 8,12 & $99 \%$ \\
\hline NOP. & $111.675 .885 .750,-$ & $13.078 .571 .930,-$ & 8,54 & $104 \%$ \\
\hline DES. & $108.926 .784 .200,-$ & $12.088 .263 .177,-$ & 9,01 & $110 \%$ \\
\hline JAN. & $114.323 .940 .051,-$ & $12.787 .945 .690,-$ & 8,94 & $109 \%$ \\
\hline
\end{tabular}

Tabel 4. Hasil Perhitungan Produktivitas Produk

\begin{tabular}{|c|r|r|c|c|}
\hline Bulan & \multicolumn{1}{|c|}{ Laba Kotor (Rp) } & Biaya langsung (Rp) & Rasio produktivitas & IP Produk \\
\hline FEB. & $91.285 .681 .418,-$ & $131.729 .909 .382,-$ & 0,69 & $100 \%$ \\
\hline MAR. & $95.131 .048 .852,-$ & $143.097 .791 .218,-$ & 0,66 & $96 \%$ \\
\hline APR. & $94.290 .123 .867,-$ & $155.799 .311 .171,-$ & 0,61 & $87 \%$ \\
\hline MEI & $106.904 .712 .131,-$ & $140.604 .210 .031,-$ & 0,76 & $110 \%$ \\
\hline JUN & $105.243 .163 .117,-$ & $152.328 .439 .811,-$ & 0,69 & $100 \%$ \\
\hline JUL & $112.232 .568 .722,-$ & $127.130 .363 .992,-$ & 0,88 & $127 \%$ \\
\hline AGU. & $89.348 .974 .581,-$ & $135.835 .406 .187,-$ & 0,66 & $95 \%$ \\
\hline SEP. & $89.496 .693 .356,-$ & $131.233 .389 .215,-$ & 0,68 & $98 \%$ \\
\hline OKT. & $95.319 .789 .363,-$ & $140.361 .151 .362,-$ & 0,68 & $98 \%$ \\
\hline NOP. & $111.675 .885 .750,-$ & $150.804 .027 .680,-$ & 0,74 & $107 \%$ \\
\hline DES. & $108.926 .784 .200,-$ & $133.713 .596 .985,-$ & 0,81 & $118 \%$ \\
\hline JAN. & $114.323 .940 .051,-$ & $142.514 .426 .466,-$ & 0,80 & $116 \%$ \\
\hline
\end{tabular}

Sumber : Data Internal Perusahaan (2018 - 2019)

Tabel 5. Hasil Perhitungan Produktivitas Tenaga Kerja

\begin{tabular}{|c|c|c|c|c|}
\hline Bulan & $\begin{array}{c}\text { Laba Kotor } \\
(\mathbf{R p})\end{array}$ & $\begin{array}{c}\text { Gaji Total } \\
\mathbf{( R p )}\end{array}$ & $\begin{array}{c}\text { Rasio } \\
\text { Produktivitas }\end{array}$ & $\begin{array}{c}\text { IP } \\
\text { Produksi }\end{array}$ \\
\hline FEB. & $91.285 .681 .418,-$ & $1.458 .407 .984,-$ & 62,59 & $100 \%$ \\
\hline MAR. & $95.131 .048 .852,-$ & $1.458 .407 .984,-$ & 65,23 & $104 \%$ \\
\hline APR. & $94.290 .123 .867,-$ & $1.458 .407 .984,-$ & 64,65 & $103 \%$ \\
\hline MEI & $106.904 .712 .131,-$ & $1.458 .407 .984,-$ & 73,30 & $117 \%$ \\
\hline JUN & $105.243 .163 .117,-$ & $1.458 .407 .984,-$ & 72,16 & $115 \%$ \\
\hline JUL & $112.232 .568 .722,-$ & $1.458 .407 .984,-$ & 76,96 & $123 \%$ \\
\hline AGU. & $89.348 .974 .581,-$ & $1.458 .407 .984,-$ & 61,26 & $98 \%$ \\
\hline SEP. & $89.496 .693 .356,-$ & $1.458 .407 .984,--$ & 61,37 & $98 \%$ \\
\hline OKT. & $95.319 .789 .363,-$ & $1.458 .407 .984,-$ & 65,36 & $104 \%$ \\
\hline NOP. & $111.675 .885 .750,-$ & $1.458 .407 .984,-$ & 76,57 & $122 \%$ \\
\hline DES. & $108.926 .784 .200,-$ & $1.458 .407 .984,--$ & 74,69 & $119 \%$ \\
\hline JAN. & $114.323 .940 .051,-$ & $1.575 .518 .164,-$ & 72,56 & $116 \%$ \\
\hline
\end{tabular}

Sumber : Data Internal Perusahaan (2018 - 2019) 
Tabel 6. Hasil Perhitungan Produktivitas Modal

\begin{tabular}{|c|c|c|c|c|}
\hline Bulan & $\begin{array}{c}\text { Pendapatan } \\
\text { Bersih (Rp) }\end{array}$ & $\begin{array}{c}\text { Modal } \\
\text { (Rp) }\end{array}$ & $\begin{array}{c}\text { Rasio } \\
\text { Produktivitas }\end{array}$ & $\begin{array}{c}\text { IP } \\
\text { Modal }\end{array}$ \\
\hline FEB. & $210.459 .456 .536,-$ & $138.016 .142 .156,-$ & 1,52 & $100 \%$ \\
\hline MAR. & $224.911 .964 .543,-$ & $149.464 .959 .157,-$ & 1,50 & $99 \%$ \\
\hline APR. & $236.179 .593 .777,-$ & $163.192,353.984,-$ & 1,45 & $95 \%$ \\
\hline MEI & $233.728 .272 .466,-$ & $148.527 .012 .021,-$ & 1,57 & $103 \%$ \\
\hline JUN & $243.287 .655 .571,-$ & $159.522 .428 .152,-$ & 1,53 & $100 \%$ \\
\hline JUL & $225.989 .305 .190,-$ & $132.879 .242 .685,-$ & 1,7 & $112 \%$ \\
\hline AGU. & $212.519 .756 .626,-$ & $144.782 .395 .959,-$ & 1,47 & $96 \%$ \\
\hline SEP. & $208.288 .391 .504,-$ & $138.566 .682 .151,-$ & 1,50 & $99 \%$ \\
\hline OKT. & $222.491 .858 .319,-$ & $148.252 .644 .145,-$ & 1,50 & $99 \%$ \\
\hline NOP. & $247.949 .706 .593,-$ & $160.915 .635 .864,-$ & 1,54 & $101 \%$ \\
\hline DES. & $229.103 .915 .295,-$ & $141.238 .810 .475,-$ & 1,62 & $106 \%$ \\
\hline JAN. & $242.481 .958 .033,-$ & $149.038 .028 .396,-$ & 1,63 & $107 \%$ \\
\hline
\end{tabular}

Setelah melakukan pengukuran produktivitas dan mengetahui hasil perhitungannya maka selanjutnya melakukan evaluasi produktivitas, dari hasil yang didapat berdasarkan grafik rasio produktivitas dan indeks produktivitas diperoleh hasil yang flutuaktif, yang artinya produktivitas Industri Baja Tulangan PT. X Surabaya perlu untuk diperbaiki dan melakukan tindakan perbaikan.

\section{Performance Prism}

Berdasarkan kertkaitan dengan stakeholder pada Industri Baja Tulangan PT. X Surabaya dapat diketahui stakeholder yang terlibat untuk aktivitas perusahaan, diantaranya;

1. Pimpinan perusahaan

Pimpinan perusahaan memiliki peranan besar dalam mengelolah Industri Baja Tulangan PT. X, dimana yang bertanggung jawab dalam melakukan perencanaan dan melakukan segala kegiatan yang berjalan pada perusahaan tersebut. Peranan tersebut dalam aktivitas usaha misalnya memberikan operasional dana dengan baik, melakukan pengawasan terhadap segala kelengkapan yang dibutuhkan perusahaan serta pengawasan terhadap skill yang dimiliki para tenaga kerja.

2. Pelanggan

Pelanggan memiliki peranan di perusahaan dalam menilai bagaimana produk tersebut diterima oleh konsumen dan memberikan penilaiannya tentang kepuasan yang dirasakan. Konsumen juga dapat memberikan saran terhadap produk yang dihasilkan Industri Baja Tulangan PT. X untuk memberikan inovasi terhadap produk tersebut. Konsumen juga diharapkan merasa puas dengan kualitas produk round barr. Yang nantinya akan memiliki kepercayaan dalam menggunakan produk tersebut.

3. Karyawan

Sebagai tenaga kerja langsung, karyawan memiliki peranan vital dalam kelangsungan aktivitas produksi di Industri Baja Tulangan PT. X. Karyawan juga dianjurkan untuk menjalankan skill yang dimiliki dengan baik untuk menghasilkan kualitas produk demi menjaga citra perusahaan. Karyawan harus dievaluasi tingkat produktivitasnya untuk mengukur bagaimana tingkat kemampuan yang dimiliki, apabila terdapat hasil yang kurang baik maka perlu dilakukan training.

4. Supplier

Peranan supplier oleh sebuah perusahaan untuk menjalankan proses produksi misalnya supplier billet, yang nantinya berpengaruh terhadap kualitas produk yang dihasilkan, apabila terdapat billet yang cacat maka Industri Baja Tulangan PT. X Surabaya berhak menerima torelansi yang berlaku sesuai dengan negoisasi oleh supplier.

5. Masyarakat

Peranan masyarakat di lingkungan sekitar harus dipertimbangkan oleh Industri Baja Tulangan PT. $X$, karena aktivitas produksi yang berdampak pada lingkungan sekitarnya. Hal yang perlu dilakukan 
misalnya program CSR (Corporate Social Responbility). Untuk menjaga kenyamanan dan kesejahteraan masyarakat sekitar.

\section{Penentuan Spesifikasi Tujuan}

Untuk penentuan spesifikasi tujuan pada tahapan Performance Prism didapatkan dari sebuah hasil kuesioner, dengan responden yang terlibat pada stakeholder dari Industri Baja Tulangan PT. X Surabaya, indentifikasi tersebut berdasarkan perspektif dari kerangka performance prism diantaranya kepuasan, strategi, proses, kapabilitas dan kontribusi, antara lain: investor, tenaga kerja, konsumen, supplier dan masyarakat. Tabel 7 hingga 11 menunjukkan perspektif setiap stakeholder yang terlibat.

Tabel 7. Spesifikasi Tujuan Stakeholder Investor

\begin{tabular}{|l|l|l|}
\hline Perspektif & Spesifikasi Tujuan & \multicolumn{1}{|c|}{ KPI } \\
\hline Kepuasan & $\begin{array}{l}\text { Pelaporan modal } \\
\text { yang transparansi }\end{array}$ & $\begin{array}{l}\text { Return On Asset } \\
\text { (ROA) }\end{array}$ \\
\hline Strategi & $\begin{array}{l}\text { Index pengeluaran } \\
\text { Modal }\end{array}$ & $\begin{array}{l}\text { Return On Invest } \\
\text { (ROI) }\end{array}$ \\
\hline Proses & $\begin{array}{l}\text { Manajemen modal } \\
\text { dan asset yang baik }\end{array}$ & $\begin{array}{l}\text { Persentase } \\
\text { peningkatan } \\
\text { margin }\end{array}$ \\
\hline Kapabilitas & Peningkatan profit & $\begin{array}{l}\text { Rasio produktivitas } \\
\text { terhadap modal }\end{array}$ \\
\hline Kontribusi & $\begin{array}{l}\text { Memberikan } \\
\text { kepuasan terhadap } \\
\text { pengalokasian dana }\end{array}$ & $\begin{array}{l}\text { Persentase } \\
\text { keuntungan } \\
\text { perusahaan }\end{array}$ \\
\hline
\end{tabular}

Tabel 8. Spesifikasi Tujuan Stakeholder Tenaga Kerja

\begin{tabular}{|c|c|c|}
\hline Stakeholder & $\begin{array}{l}\text { Spesifikasi } \\
\text { Tujuan }\end{array}$ & $\mathrm{KPI}$ \\
\hline Kepuasan & $\begin{array}{l}\text { Kedisiplinan } \\
\text { tenaga kerja } \\
\text { yang sudah } \\
\text { dilakukan }\end{array}$ & $\begin{array}{l}\text { Tingkat pelanggaran } \\
\text { tenaga kerja }\end{array}$ \\
\hline Strategi & $\begin{array}{l}\text { Terjaminnya } \\
\text { tunjangan sosial } \\
\text { dan kesehatan }\end{array}$ & $\begin{array}{ll}\text { Persentase } & \text { keluhan } \\
\text { terhadap } & \text { jaminan } \\
\text { sosial dan kesehatan }\end{array}$ \\
\hline Proses & $\begin{array}{l}\text { Tingkat } \\
\text { kepuasan } \\
\text { karyawan }\end{array}$ & $\begin{array}{lr}\text { Persentase } & \text { tenaga } \\
\text { kerja puas } & \text { dan } \\
\text { nyaman } & \text { dengan } \\
\text { lingkungan } & \end{array}$ \\
\hline Kapabilitas & $\begin{array}{l}\text { Tingkat pelatihan } \\
\text { yang dilakukan }\end{array}$ & $\begin{array}{l}\text { Produktivitas tenaga } \\
\text { kerja }\end{array}$ \\
\hline Kontribusi & $\begin{array}{l}\text { Mengetahui } \\
\text { toleransi } \\
\text { kebijakan } \\
\text { perusahaan yang } \\
\text { dapat diterima }\end{array}$ & $\begin{array}{l}\text { Tingkat kedisiplinan } \\
\text { tenaga kerja }\end{array}$ \\
\hline
\end{tabular}

Berdasarkan indentifikasi dari beberapa tabel diatas dapat diketahui penjabaran spesifikasi tujuan dan Key Performance Indicator pada setiap perspektif dari stakeholder Industri Baja Tulangan PT. X Surabaya.
Tabel 9. Spesifikasi Tujuan Stakeholder Konsumen

\begin{tabular}{|l|l|l|}
\hline Stakeholder & \multicolumn{1}{|c|}{ Spesifikasi Tujuan } & \multicolumn{1}{c|}{ KPI } \\
\hline Kepuasan & $\begin{array}{l}\text { Kepuasan terhadap } \\
\text { produk yang diterima }\end{array}$ & $\begin{array}{l}\text { Persentase } \\
\text { produk cacat }\end{array}$ \\
\hline Strategi & $\begin{array}{l}\text { Menerima segala } \\
\text { keluhan dari pelanggan }\end{array}$ & $\begin{array}{l}\text { Persentase } \\
\text { keluhan } \\
\text { yang dilayani }\end{array}$ \\
\hline Proses & $\begin{array}{l}\text { Kemampuan memenuhi } \\
\text { kebutuhan pelanggan }\end{array}$ & $\begin{array}{l}\text { Tingkat } \\
\text { pertumbuhan } \\
\text { pelanggan }\end{array}$ \\
\hline Kapabilitas & $\begin{array}{l}\text { Frekuensi tingkat } \\
\text { kepuasan pelanggan }\end{array}$ & $\begin{array}{l}\text { Tingkat } \\
\text { kepuasan } \\
\text { pelanggan }\end{array}$ \\
\hline Kontribusi & $\begin{array}{l}\text { Perusahaan dapat } \\
\text { mengerti konsumen yang } \\
\text { loyal }\end{array}$ & $\begin{array}{l}\text { Persentase } \\
\text { konsumen } \\
\text { yang loyal }\end{array}$ \\
\hline
\end{tabular}

Tabel 10. Spesifikasi Tujuan Stakeholder Supplier

\begin{tabular}{|l|l|l|}
\hline Stakeholder & Spesifikasi Tujuan & \multicolumn{1}{|c|}{ KPI } \\
\hline Kepuasan & $\begin{array}{l}\text { Ketepatan waktu } \\
\text { yang baik dalam } \\
\text { pembayaran }\end{array}$ & $\begin{array}{l}\text { Persentase } \\
\text { pembayaran } \\
\text { tepat waktu }\end{array}$ \\
\hline Strategi & $\begin{array}{l}\text { Index kepuasan } \\
\text { supplier }\end{array}$ & $\begin{array}{l}\text { Persentase } \\
\text { peningkatan } \\
\text { pembelihan }\end{array}$ \\
\hline Proses & $\begin{array}{l}\text { Pengukuran tingkat } \\
\text { kemajuan }\end{array}$ & $\begin{array}{l}\text { Persentase } \\
\text { kewajiban } \\
\text { terpenuhi }\end{array}$ \\
\hline Kapabilitas & Kesesuaian produk & $\begin{array}{l}\text { Persentase } \\
\text { material } \\
\text { cacat }\end{array}$ \\
\hline Kontribusi & $\begin{array}{l}\text { Pengiriman bahan } \\
\text { baku tepat pada } \\
\text { waktunya }\end{array}$ & $\begin{array}{l}\text { Persentase } \\
\text { pengiriman } \\
\text { tepat waktu }\end{array}$ \\
\hline
\end{tabular}

Tabel 11. Spesifikasi Tujuan Stakeholder Masyarakat

\begin{tabular}{|l|l|l|}
\hline Stakeholder & Spesifikasi Tujuan & \multicolumn{1}{|c|}{ KPI } \\
\hline Kepuasan & $\begin{array}{l}\text { Tanggap pada } \\
\text { keluhan } \\
\text { masyarakat }\end{array}$ & $\begin{array}{l}\text { Tingkat } \\
\text { mengatasi } \\
\text { keluhan } \\
\text { masyarakat }\end{array}$ \\
\hline Strategi & $\begin{array}{l}\text { Tingkat aktivitas } \\
\text { social }\end{array}$ & $\begin{array}{l}\text { Tingkat } \\
\text { pengembangan } \\
\text { pelatihan } \\
\text { kepada } \\
\text { masyarakat }\end{array}$ \\
\hline Proses & $\begin{array}{l}\text { Pengembangan } \\
\text { CSR }\end{array}$ & $\begin{array}{l}\text { Tingkat hasil } \\
\text { kegiatan CSR }\end{array}$ \\
\hline Kapabilitas & $\begin{array}{l}\text { Menciptakan } \\
\text { kedekatan dan } \\
\text { kepercayaan } \\
\text { masyarakat }\end{array}$ & $\begin{array}{l}\text { Tingkat } \\
\text { kepuasan } \\
\text { masyarakat }\end{array}$ \\
\hline Kontribusi & $\begin{array}{l}\text { Progam CSR } \\
\text { dilaksanakan } \\
\text { sesuai dengan } \\
\text { kebutuhan } \\
\text { masyarakat }\end{array}$ & $\begin{array}{l}\text { Tingkat } \\
\text { kepuasan hasil } \\
\text { CSR }\end{array}$ \\
\hline
\end{tabular}

\section{Penjabaran Spesifikasi Pengukuran Berdasarkan indikator POSPAC dari Pencapaian KPI (Key Performance Indikator)}

Pada tahapan ini dilakukan pengukuran berdasarkan pencapain $\mathrm{KPI}$ dari indikator POSPAC (Produksi, Organisasi, Penjualan, Produk, Tenaga Kerja, dan Modal). Dapat diketahui hasil pengukuran kinerja yang disajikan di Tabel 12. 
Berdasarkan Tabel 12 maka peneliti melakukan FGD (Focus Group Discussion) dengan pihak-pihak yang dianggap berkompeten untuk memberikan usulan atau saran peningkatan produktivitas terutama terkait dengan pencapaian target perusahaan. Pihak-pihak tersebut antara lain: Kepala pabrik (1 orang), manajer operasional (1 orang), karyawan senior di bidang produksi (1 orang), karyawan senior di bidang teknik (1 orang), pihak supplier (1 orang) dan peneliti, dimana rekomendasi yang dihasilkan antara lain:

1. Tingkat pelanggaran tenaga kerja

Untuk memperbaiki tingkat pelanggaran yang terjadi oleh tenaga kerja maka perlu dilakukan beberapa upaya tindakan sebagai berikut.

a. Membuat aturan organisasi secara jelas dan tersosialisasi baik karyawan baru dan lama.

b. Memberikan pemahaman tentang pentingnya kedisiplinan tenaga kerja bagi karyawan terhadap perusahaan baik level pimpinan, lini, middle dan top management.

c. Memberikan contoh tentang kedisiplinan tenaga kerja dan ketaatan aturan

d. Melakukan fungsi dan control secara prefentif oleh pimpinan secara langsung terhadap tenaga kerja

e. Menerapkan konsep reward dan punishment dimana tenaga kerja yang disiplin diberikan reward dan yang melanggar diberikan punishment

2. Tingkat Kedisiplinan Tenaga kerja

Dalam menciptakan tingkat kedisiplinan tenaga kerja terhadap aturan perusahaan yang berlaku, oleh sebab itu perlu adanya perbakan yang meliputi:

a. Menerapkan sistem gaji dari capain Key Performance Indicator yang ada di perusahaan PT. X Surabaya

b. Adanya pemotongan gaji bagi tenaga kerja yang terlambat

c. Melakukan pengawasan oleh pimpinan langsung

d. Melakukan pelaporan secara rutin terhadap capaian hasil pekerjaan kepada pimpinan langsung

e. Pemberian reward terhadap reward untuk tenaga kerja yang mencapai target sehingga dapat termotivasi dalam menjalankan aktivitas bekerjanya.
Tabel 12. Penjabaran Spesifikasi Pengukuran Berdasarkan Indikator POSPAC dari Pencapaian KPI

\begin{tabular}{|c|c|c|c|}
\hline $\begin{array}{c}\text { Indikator } \\
\text { Produktivitas }\end{array}$ & Indikator Kinerja & Nilai & Target \\
\hline \multirow[t]{2}{*}{ Produksi } & $\begin{array}{l}\text { Persentase } \\
\text { peningkatan } \\
\text { pembelian bahan } \\
\text { baku }\end{array}$ & $12 \%$ & $30 \%$ \\
\hline & $\begin{array}{l}\text { Persentase } \\
\text { peningkatan margin }\end{array}$ & $42 \%$ & $30 \%$ \\
\hline \multirow{8}{*}{ Organisasi } & $\begin{array}{l}\text { Persentase Keluhan } \\
\text { yang dilayani }\end{array}$ & $92 \%$ & $90 \%$ \\
\hline & $\begin{array}{l}\text { Tingkat mengatasi } \\
\text { keluhan masyarakat }\end{array}$ & $100 \%$ & $90 \%$ \\
\hline & $\begin{array}{l}\text { Tingkat } \\
\text { pengembangan } \\
\text { pelatihan kepada } \\
\text { masyarakat }\end{array}$ & $100 \%$ & $90 \%$ \\
\hline & $\begin{array}{l}\text { Tingkat hasil } \\
\text { kegiatan CSR }\end{array}$ & $100 \%$ & $90 \%$ \\
\hline & $\begin{array}{l}\text { Tingkat kepuasan } \\
\text { masyarakat }\end{array}$ & $85 \%$ & $80 \%$ \\
\hline & $\begin{array}{l}\text { Tingkat kepuasan } \\
\text { hasil CSR }\end{array}$ & $86 \%$ & $80 \%$ \\
\hline & $\begin{array}{l}\text { Persentase } \\
\text { kewajiban terpenuhi }\end{array}$ & $100 \%$ & $90 \%$ \\
\hline & $\begin{array}{l}\text { Persentase } \\
\text { pembayaran tepat } \\
\text { waktu }\end{array}$ & $76 \%$ & $90 \%$ \\
\hline \multirow{3}{*}{ Penjualan } & $\begin{array}{l}\text { Persentase } \\
\text { Keuntungan } \\
\text { Perusahaan } \\
\end{array}$ & $154 \%$ & $100 \%$ \\
\hline & $\begin{array}{ll}\text { Tingkat kepuasan } \\
\text { pelanggan }\end{array}$ & $92 \%$ & $90 \%$ \\
\hline & $\begin{array}{l}\text { Tingkat Pertumbuhan } \\
\text { Pelanggan }\end{array}$ & $12 \%$ & $10 \%$ \\
\hline \multirow{4}{*}{ Produk } & $\begin{array}{l}\text { Persentase produk } \\
\text { cacat }\end{array}$ & $15 \%$ & $5 \%$ \\
\hline & $\begin{array}{l}\text { Persentase material } \\
\text { cacat }\end{array}$ & $5 \%$ & $5 \%$ \\
\hline & $\begin{array}{l}\text { Persentase } \\
\text { pengiriman tepat } \\
\text { waktu }\end{array}$ & $93 \%$ & $90 \%$ \\
\hline & $\begin{array}{l}\text { Persentase } \\
\text { konsumen yang loyal }\end{array}$ & $55 \%$ & $90 \%$ \\
\hline \multirow{5}{*}{ Tenaga Kerja } & $\begin{array}{l}\text { Tingkat pelanggaran } \\
\text { tenaga kerja }\end{array}$ & $29 \%$ & $10 \%$ \\
\hline & $\begin{array}{l}\text { Persentase keluhan } \\
\text { terhadap jaminan } \\
\text { sosial dan kesehatan }\end{array}$ & $9 \%$ & $10 \%$ \\
\hline & $\begin{array}{lr}\text { Persentase } & \text { tenaga } \\
\text { kerja puas } & \text { dan } \\
\text { nyaman } & \text { dengan } \\
\text { lingkungan } & \end{array}$ & $98 \%$ & $90 \%$ \\
\hline & $\begin{array}{l}\text { Produktivitas tenaga } \\
\text { kerja }\end{array}$ & 68,91 & 1,00 \\
\hline & $\begin{array}{l}\text { Tingkat kedisiplinan } \\
\text { tenaga kerja }\end{array}$ & $71 \%$ & $90 \%$ \\
\hline \multirow{3}{*}{ Modal } & $\begin{array}{l}\begin{array}{l}\text { Return On Invest } \\
\text { (ROI) }\end{array} \\
\end{array}$ & $\begin{array}{c}114 \\
\%\end{array}$ & $100 \%$ \\
\hline & $\begin{array}{l}\begin{array}{l}\text { Return On Asset } \\
\text { (ROA) }\end{array} \\
\end{array}$ & $\begin{array}{c}428 \\
\% \\
\end{array}$ & $100 \%$ \\
\hline & $\begin{array}{l}\text { Rasio Produktivitas } \\
\text { terhadap modal }\end{array}$ & 1,55 & 1,00 \\
\hline
\end{tabular}

3. Persentase Konsumen yang Loyal

Untuk meningkatkan konsumen yang loyal dapat dilakukan usulan perbaikan berikut ini:

a. Memberikan penawaran khusus untuk member atau pelanggan 
b. Memberikan kualitas layanan dan produk yang terbaik untuk pelanggan

c. Memelihara hubungan timbal balik kepada konsumen

d. Memberikan layanan customer service yang responsive

e. Memberikan jaminan produk

4. Persentase pembayaran tepat waktu Untuk mengatasi permasalahan pembayaran tepat waktu, hal yang perlu diperhatikan yaitu:

a. Membuat dual contract terkait dengan kewajiban hak terkait dengan kewajiban pemenuhan barang, jangka waktu pembayaran yang disepakati (denda pembayaran serta clausul garansi dan jaminan)

b. Adanya pihak ketiga sebagai penjamin (laison guwanted) misalnya bank.

5. Persentase produk cacat

Untuk meminimalisir produk cacat dapat dilakukan sebuah tindakan perbakan yang meliputi:

a. Membuat jadwal maintenance secara rutin

b. Melakukan inspeksi pada saat produksi sedang berlangsung

c. Memilih material yang berkualitas baik

d. Melakukan perbaikan metode kerja pada proses produksi

e. Memilih mesin yang berkualitas baik

6. Persentase peningkatan pembelian bahan baku

Untuk meningkatan jumlah pembelihan bahan baku dengan supplier dengan melakukan tindakan sebagai berikut:

a. Melakukan forecasting atau peramalan pembelian

b. bahan baku dengan baik

c. Memilih banyak relasi hubungan dengan supplier

d. Menggunakan alternatif bahan baku pengganti

\section{Kesimpulan}

Berdasarkan penelitian yang telah dikaji dari hasil yang telah diperoleh maka dapat ditarik beberapa kesimpulan, sebagai berikut;

1. Dalam identifikasi pengukuran produktivitas POSPAC didapatkan hasil nilai yang flutuaktif dari setiap bulan pada indikatornya dan diperoleh hasil rasio produktivitas tertinggi pada indikator Tenaga kerja pada periode Juli dengan rasio produktivitas sebesar 76,96 dan indeks produktivitas sebesar 123\%, untuk pengukuran produktivitas terendah pada indikator produk pada periode dengan nilai rasio produktivitas sebesar 0,61 dan indeks produktivitas sebesar $87 \%$.

2. Berdasarkan penjabaran spesifikasi tujuan kinerja dapat diketahui pencapaian target yang perlu untuk dilakukan evaluasi berdasarkan indikator dari KPI Industri Baja Tulangan PT. $X$.

3. Dari hasil penjabaran penelitian dapat diketahui pencapaian nilai yang dinyatakan belum mencapai target perusahan dan perlu dilakukan evaluasi untuk meningkatkan kinerja persahaan Industri Baja Tulangan PT. X Surabaya.

\section{Daftar Pustaka}

Agustina, F. (2011). Analisis Produktivitas dengan Metode Objective Matrix (OMAX) di PT . X, 6(2), 150-158.

Neely, A., Adams, C., and Kennerley, M. (2012). The Performance Prism: The Scorecard for Measuring and Managing Business Success. United Kingdom: Copyright Licensing Agency Ktd.

Prabowo, R. (2017). Pengendalian Persediaan Bahan Baku Oli Untuk Mesin Diesel Tipe G4J-801, G5J-801 dan G7J-801 di PT. Hansan Asembling-Malang. PROZIMA (Productivity, Optimization and Manufacturing System Engineering), 1(1), 33-43.

Prabowo, R. (2016). Penerapan Konsep Line Balancing Untuk Mencapai Efisiensi Kerja yang Optimal pada Setiap Stasiun Kerja pada PT. HM. Sampoerna Tbk. Jurnal IPTEK, 20(2), 9-20.

Purnomo, C. A. \& Hadi, Y. (2017). Pengukuran Kinerja Menggunakan Performance Prism. Malang; Jurnal Teknik Industri Universitas Ma Chung Malang.

Ramadhani, Y. (2011). Analisis efisiensi, skala dan elastisitas produksi dengan pendekatan cobb-douglas dan regresi berganda. Jurnal Teknologi 4(1): 53-61

Supriyanto, F. J., Yusuf, Y., \& Wisnubroto. (2014). Analisis Produktivitas menggunakan Metode Cobb Douglas dan Metode Habberstad (POSPAC). Yogyakarta: Jurnal 
Teknik Industri AKPRIND

Suryanto, K.W. (2014). Tingkat Produktivitas Total dan Parsial PT. United Tractors Menggunakan Model Davis J. Sumanth dan Habberstad (POSPAC) yang Disesuaikan, Jurnal Teknik Industri ITB, Bandung.

Syarifuddin \& Yani L. (2014). Analisis Produktivitas Perusahaan pada UD. Karya Jaya. Aceh: Jurnal Jurusan Teknik Industri Universitas Mallikus Saleh

Syarifuddin, Syukriah, \& Jen R. M. (2017). Analisis Produktivitas Perusahaan Dengan Menggunakan Metode POSPAC di PT. Supra Matra Abadi. Aceh: Jurnal Teknik Industri Universitas Malikus Saleh

Wibowo, S. A (2018) Usulan Peningkatan Produktivitas menggunakan Lean Manufacturing Dengan VSM. Yogyakarta: Jurnal Teknik Industri Universitas Islam Indonesia

Widodo, E., Takahashi, K., Morikawa, K., Pujawan, I. N., \& Santosa, B. (2009, December). Managing sales return in dual sales channel: An analysis of its product substitution. In Proceeding of Asia Pacific Industrial Engineering and Management System Conference (pp. 823-835). 
Halaman ini sengaja dikosongkan

This page is intentionally left blank 